\title{
A NUMERICAL MODEL OF THE GREAT PLAINS SQUALL LINE THUNDERSTORM
}

by

Carl E. Hane

Oral Presentation at

Eighth Conference on Severe Local Storms

Denver, Colorado

and

for publication in the Proceedings

October 1973

This work was performed by $\mathrm{Dr}$. Hane during his previous appointment at NCAR in Boulder, Colorado. This work will be extended in future AEC research at Battelle, Pacific Northwest Laboratories, Richland, Washington.

\section{NOTICE}

This report was prepared as an account of work sponsored by the United States Government. Neither the United States nor the United States Atomic Energy Commission, nor any of their employees, nor any of their contractors, subcontractors, or their employees, makes any warranty, express or implied, or assumes any legal liability or responsibility for the accuracy, completeness or usefulness of any information, apparatus, product or process disclosed, or represents that its use would not infringe privately owned rights. 


\section{DISCLAIMER}

This report was prepared as an account of work sponsored by an agency of the United States Government. Neither the United States Government nor any agency Thereof, nor any of their employees, makes any warranty, express or implied, or assumes any legal liability or responsibility for the accuracy, completeness, or usefulness of any information, apparatus, product, or process disclosed, or represents that its use would not infringe privately owned rights. Reference herein to any specific commercial product, process, or service by trade name, trademark, manufacturer, or otherwise does not necessarily constitute or imply its endorsement, recommendation, or favoring by the United States Government or any agency thereof. The views and opinions of authors expressed herein do not necessarily state or reflect those of the United States Government or any agency thereof. 


\section{DISCLAIMER}

Portions of this document may be illegible in electronic image products. Images are produced from the best available original document. 


\section{The following pages are an exact representation of what is in the original document folder.}




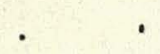

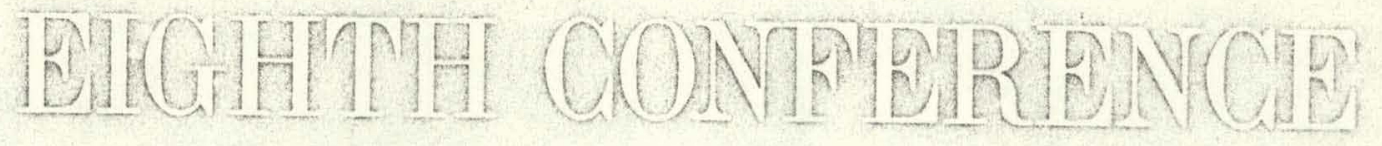 (O) N}

\section{SIEVIERIE LOOCAUL STOORIMS}

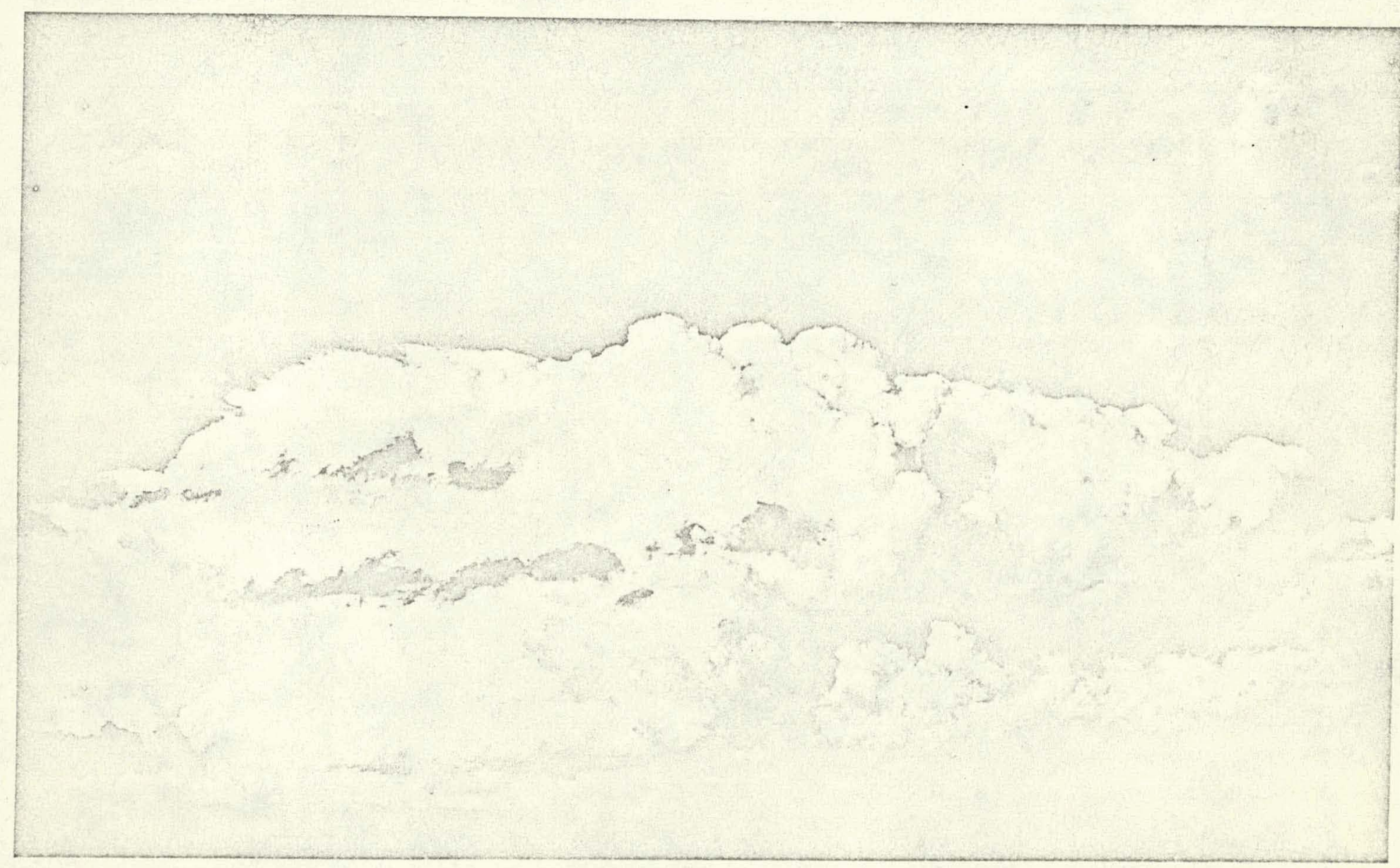

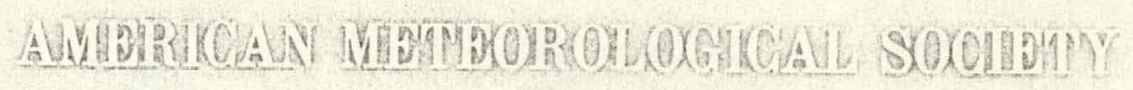

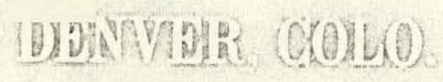


A NUMERICAL MODEL OF THE

GREAT PLAINS SQUALL LINE THUNDERSTORM

Car1 E. Hane

National Center for Atmospher1c Research* Boulder, Colorado 80302

\section{INTRODUCTION}

The squall line thunderstorm of the Great Plalns possesses several outstanilng characterlst1cs which warrant much investigation and explanation. For one, the squall ine thunderstorm is very persistent in the sense that the individual thunderstorm elther lasts a long time or creates conditions necessary for redevelopment following its dissipation. Secondly it exists in an environment characterlzed by strong vertical shear of the horizontal wind and pronounced dryness in middle levels. That the thunderstorm should exist under such conditions, at first glance, seems paradoxical.

However, in the last twenty-five years or so, certain ideas have been expressed to attempt to explain th1s apparent paradox. Newton (1950) suggested that the Interaction of the strong upand downdrafts with the environment tends to favor a downshear propagation of the system. He also reasoned that the strong shear allows for the relative inflow of potentially warm air in low levels and potentially cold alr in middle levels, favorable for the maintenance of updrafts and downdrafts respectively.

Another important point is that regarding the shape of the updraft within the mature cloud Bates (1961), Browning and Ludlam (1962), and Newton (1963) have all noted that it is quite likely that the main updraft in large storms is inclined in an upshear direction through an appreclable deplh of the cloud. Fig. I is a schematic drawing which combines and summarizes this idea and the earlier 1dea concerning the istrong shear. Here, the two-dimensional a1r flow within a traveling convective storm 1s shown with the downdraft within the cloud coexisting just upshear from the upshear tilting updraft. Such an arrangement of updraft and downdraft allows the rain to fall from the updraft, relleving the updraft of this regarding force, and allows the rain to fall into a region which is most favorable for the production of negative buoyancy through evaporation. Because of the strong shear, the updraft is continually replenished by the incoming warm molst low-level air, and the downdraft con-

* The National Center for Atmospheric Research $1_{8}$ spensored by the National Scleince Foundation. tinually sustained by the dry middle-level alr overtaking the system. The downward transport of horizontal momentum by the downdraft leads to a convergent area in low levels on the downshear s1de of the system, resulting in maintenance of the existing updraft or generation of a new one. Thus, the aystem is able to convert the potential energy of 1 ts environment 1nto the kinetic energy which 18 necessary for 1 ts maintenance, an Idea first stated by Normand (1946).

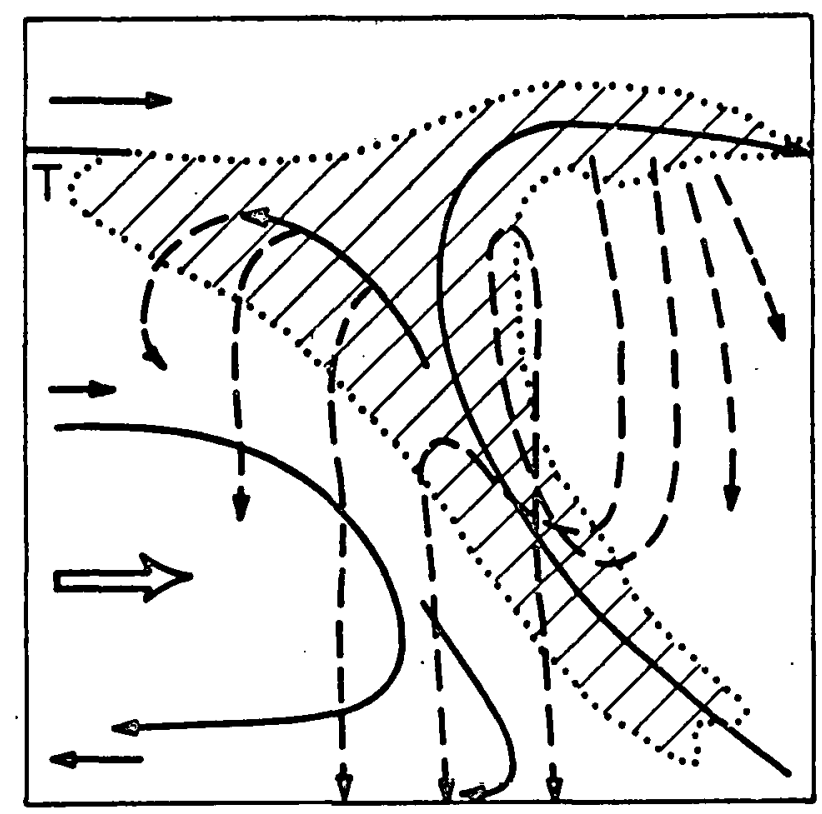

F18. 1. Schematic representation of the motion fleld within a middle-latitude cumulonimbus in wind shear (after Ludlatn, 1961).

The testing of the above-mentioned ideas awalts the analysis of observations taken within squall line thunderstorms. In the meantime, a reasonable approach seems to be to use the data which is available in the 1mmediate surroundings of such storms in specifying initial and boundary conditions for the numerical modeling of such systems. The numerical modeling of both dry and molst convection has been carried out since the early dry thermal experiments of Malkus and Witt (1959). Molature was introduced a few years later by Ogura (1963), but these early modelo were beset 
with numerical difficulties which were not overcome until the mid-60's. The work of Kessler, Newburg, Feter1s, and Wickham (1961-1964) in the area of microphysics of cloud and rain led to the inclusion of liquid water in these models in the late $1960^{\prime} s$ and early $1970^{\prime} s$ by Ámason, Greenfleld, and Newburg (1968), Orville and Liu (1969), Murray (1970), and Takeda (1971). Srivastava (1967) had earlier included explictt treatment of cloud and rain in a one-dimensional experiment. Other one-dimensional experiments, including those of Squires and Turner (1962), Simpson and W1ggert (1969), Weinstein (1970), Ogura and Takahash1 (1971), and Danfelsen, Bleck, and Morr1s (1972) have included consideration of the 1ce phase in their calculations.

Attempts in the past almed specifically at numerically modelling the squall line have been very few. Early attempts by Sasak1 (1959) and also by Ogura and Charney (1962) d1d not expl1c1tly treat the individual clouds and their internal circulations, but dealt with the problem on a much larger scale. More recently, Takeda has modeled what he calls a "long lasting cloud," which resembles the squall line thunderstorm in that it is persistent, but occurs under wind shear conditions unlike those found in squall ine situations. More recently, Schlesinger (1972) and hane (1972) have treated the squall line spectfically, and on the cloud scale.

\section{THE MODEL}

The model to be presented here 18 twodimensional, varlations along the line being neglected. The figures which w111 be presented showing the model results will therefore be vertical cross-sections through the squall line. The consequences of imposing this two-dimensional restriction will be discussed in the result section.

To initlate the calculations, a disturbance 1s superimposed upon an environment possessing the characteristics noted in the introduction, and the approprlate physical equations are integrated numericaliy to study the time evolution of the system. It is the goal here that the model $81 \mathrm{~m}$ ulate the observed long-lasting character of the squall line through elther (a) the attalnment of a quas1-steady cooperative updraft-downdraft system continuously interacting with its environment, or (b) a succession of developments, each containing the ingredients necessary for redevelopment following dissipation. In addition, the effect of vertical shear of the environmental wind will be studied by variation of the shear from one experiment to another.

In the model certain physical processes and characteristics are included, while others are not. Included are: (1) the oondensatinn and evaporation processes and their assoctated temperature changes, (2) 11quid water "in bulk" assuming a Marshall-Palmer (1948) discribution of drop sizes, (3) the fallout of rain including variable terminal fall speeds, and (4) turbulent mixing by scales of motion not resolvable by the 400-meter grid. Not 1ncluded are: (1) the 1ce phase, (2) horizontal and time changes in air density, (3) radiational effects, and (4) the exchange of heat, molature, and momentum between the alr and the earth's surface.
The basic model equations include timedependent equations for the vorticity, temperature, and for the mixing rat10s of water vapor, cloudwater, and ralnwater. The other basic equation relates the vorticlty to the stream function. The vorticity equation may be shown (Hane, 1972) to be:

$$
\begin{aligned}
\frac{\partial \eta}{\partial t}= & -u \frac{\partial \eta}{\partial x}-w \frac{\partial \eta}{\partial z}-n D_{v}-\frac{g}{T_{v}} \frac{\partial T}{\partial x} \\
& +8 \frac{\partial}{\partial x}\left(q_{\ell}+q_{c}\right)+c_{M}\left\{\frac{\partial}{\partial z}\left[\left|\frac{\partial w}{\partial x}\right|\left(u^{\prime \prime}-u\right)\right]\right. \\
& \left.-\frac{\partial}{\partial x}\left[\left|\frac{\partial w}{\partial x}\right|\left(w^{\prime \prime}-w\right)\right]\right\}+\frac{\partial}{\partial x}\left[v_{x} \frac{\partial \eta}{\partial x}\right] \\
& +\frac{\partial}{\partial z}\left[v_{z} \frac{\partial \eta}{\partial z}\right]
\end{aligned}
$$

where the vorticlty $n-\partial u / \partial z-\partial w / \partial x, u$ is the horlzontal wind speed, w the vertical wind opeed, $D_{v}=\partial u / \partial x+\partial w / \partial z, T_{v}$ 1s the virtual temperature, $q_{q}$ the ralnwater mixing ratio, $q_{c}$ the cloudwater mixing rat10, $c_{M}$ the turbulent mixing coefficlent, $u$ " and w" tire invarlant vertical distr1butions of the horizontal and vertical motion, respectively, characteristic of the environment, and $v_{x}$ and $v_{z}$ the time-space dependent horizontal and vertical eddy viscosity coefficients. For a discussion of these coefficlents see Hane (1972). The equation of continulty takes the following form:

$$
\frac{\partial}{\partial x}(\rho u)+\frac{\partial}{\partial z}(\rho w)=0 .
$$

where $p$ 1s alr density. A stream function may thus be defined

$$
\rho u=\frac{\partial \psi}{\partial z} \text { and } \rho w=-\frac{\partial \psi}{\partial x}
$$

leading to the diagnostic relation between vorticlty and stream function:

$$
\nabla^{2} \psi-\frac{1}{\rho} \frac{\partial \psi}{\partial z} \frac{\partial \rho}{\partial z}=\rho \eta .
$$

A term contalning the horlzontal gradient in alr density has been neglected here. The first law of thermodynamics. has the following form:

$$
\begin{aligned}
\frac{\partial T}{\partial t}= & -u \frac{\partial T}{\partial x}-w\left[\frac{\partial T}{\partial z}+\Gamma_{d}\right]+\frac{1}{c_{p}} \frac{d Q}{d t} \\
& +c_{M}\left|\frac{\partial w}{\partial x}\right|\left(T^{\prime \prime}-T\right)+v_{\theta} \nabla^{2} T,
\end{aligned}
$$

where $T$ is the absolute temperature, $\Gamma_{d}$ the dry adlabat1c lapse rate, $\left(1 / c_{p}\right)(d Q / d t)$ the latent heating or cooling rate, $T^{p}$ the time invariant vertical profile of temperature characteristic of
the environment, and $v_{\theta}$ the constant $\left(500 \mathrm{~m}^{2} \mathrm{sec}-1\right)$ coefficlent of thermal eddy diffusion. The equations involving the molsture are three in number.

$$
\begin{aligned}
\frac{\partial q_{v}}{\partial \tau}= & -u \frac{\partial q_{v}}{\partial x}-w \frac{\partial q_{v}}{\partial z}+c_{v}\left|\frac{\partial w}{\partial x}\right|\left(q_{v}^{\prime \prime}-q_{v}\right) \\
& +v_{\theta} \nabla^{2} q_{v}+\text { evaporation - condensation. }
\end{aligned}
$$




$$
\begin{aligned}
\frac{\partial q_{c}}{\partial t}= & -u \frac{\partial q_{c}}{\partial x}-w \frac{\partial q_{c}}{\partial z}+q_{M}\left|\frac{\partial w}{\partial x}\right|\left(q_{c}^{\prime \prime}-q_{c}\right) \\
& +v_{\theta} \nabla^{2} q_{c}-\text { autoconversion - accretion } \\
& - \text { evaporation }+ \text { condensation. } \\
\frac{\partial q_{\ell}}{\partial t}= & -u \frac{\partial q_{\ell}}{\partial x}-w \frac{\partial q_{\ell}}{\partial z}+\frac{\partial}{\partial z}\left(q_{\ell} v_{T}\right)+\frac{q_{\ell} v_{T}}{p} \frac{\partial p}{\partial z} \\
& + \text { autoconversion }+ \text { accretion } \\
& - \text { evaporation. }
\end{aligned}
$$

Here, $q_{v}$ is the water vapor mixing ratio and $q_{v}^{\prime \prime}$ and $q_{c} "$ are $t 1 \mathrm{me}$ invariant vertical profiles of the water vapor and cloudwater mixing ratios, respectively, characteristic of the environment. The turbulent mixing term, appearing in all the time-dependent equations except Eq. (7), is discussed at length in Hane (1972), as are the autoconversion, accretion, rainwater fallspeed, and rainfall evaforation expressions which are based upon the work of Kessler, et al. (15611964).

\section{COMPUTATIONAL PROCEDURES, BOUNDARY CONDI- TIONS, AND INITIAL CONDITIONS}

The time integration scheme used is a predictor-corrector scheme, which means that Eqs. (1), (3), (4), (5), (6), and (7) are solved twice during each time step. The length of each time step is varlable, depending upon the magnicude of alr motions, but generally lies in the 15-20 sec range. The grid distance 18400 meters in both the horizontal and vertical, while the total domain of integration varies in size from $25.6 \mathrm{~km}$ (horizontally) by $12.8 \mathrm{~km}$ (vertically) to $38.0 \mathrm{~km}$ (horizontally) by $12.8 \mathrm{~km}$. No flow $1 \mathrm{~s}$ allowed through the top and bottom boundarles. The flow through the lateral boundaries is fixed with time, and the values of other varlables along the lateral boundarles are determined by an inflow-outflow condition at those boundarles. Temperature and water vapor are determined along the lower boundary by setting the anomaly of temperature and of water vapor equal to that at the next higher row of grid points (400 meters).

As was mentioned earlier, the purpose here is to study the structure and tendency for selfmaintenance of the squall line thunderstorm. The problem of squall 11ne development is another question and is not considered here. With this in mind, the form and intensity of the initial perturbation is not important, as long as 1 to does not influence the structure of the system at later times. Various initial perturbations were tried with the result that there was a tendency toward convergence upon a common solution after an amount of time which increased as a function of the initial difference between perturbations. In the cases reported upon here, the 1nitlal perturbation is a well-developed thunderstormlike clrculation. Other cases have been tried beginning with a "dry line" type situation, where a low-level convergent zone is superimposed upon a low-level horfzontal mofsture gradient.' In che latcer case the sane bastc structure 18 ar- rived at after two to three hours as was arrived at after a few minutes in the former case. This being the case, only the inftial environmental profiles and not the intial perturbations will be shown here.

Figure 2 shows the environmental temperature and molsture profiles which were used in all the experiments to be described. The environment is quite unstable with a sharp drop in the molsture profile between 600 and $500 \mathrm{mb}$. The soundIng 18 typical of observed soundings taken prior to squall line passage. Figure 3 shows the profiles of the environmental wind used in each experiment. The curves plotted show wind speeds relative to the earth, although the winds used In tho computationo ate those golativa to the moving disturbance. The numbers in parentheses next to each curve denote the approximate rate of motion (m $\mathrm{sec}^{-1}$ ) of the system in each case. In practice each of these speeds 1 s determined by finding that speed which, when subtracted from the air motion relative to the earth, renders the disturbance stationary with respect to the side boundarles throughout the period of the disturbance's existence. The wind profiles in the "moderate" and "strong" cases are within the range of those observed in nature in squall line situations, although cases with much stronger shear are not uncommon.

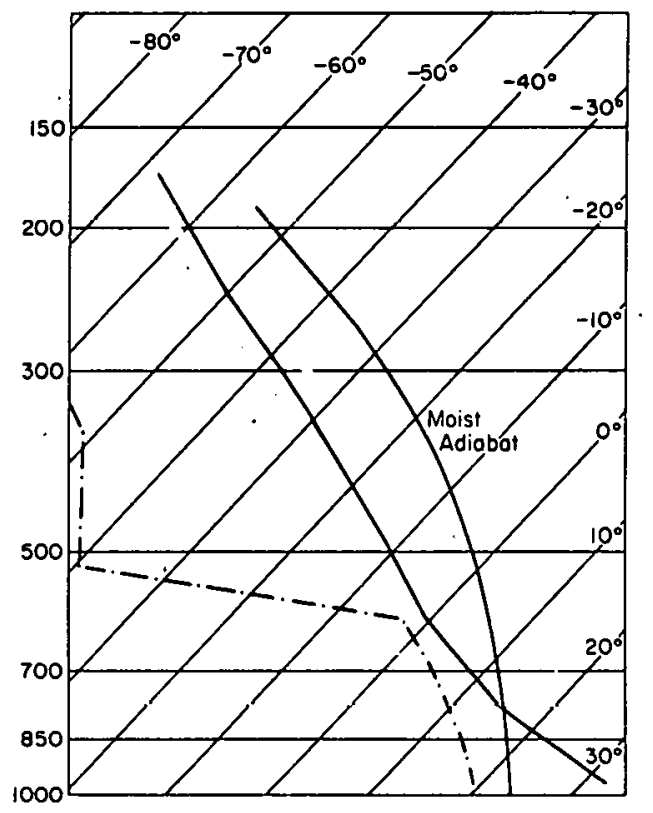

F1g. 2. Initial vertical distribution of environmental temperature (solid) and environmental dew point (dash-dotted).

A more detalled discussion of computational procedures, model boundary conditions, and initlal conditions (excluding the "dry line" case) 16 included in Hane (1972).

\section{RESULTS OF COMPUTATIONS}

Table I summarizes the experiments which were run using the varlous environmental wind prof1les. Two of the experiments ( $R 6$ and $R 7$ ) were run on a larger grid for a longer perlod of time using the same shear distributions as were used in shorier exper1ments (R1 and R2, respect'1ve1y). 


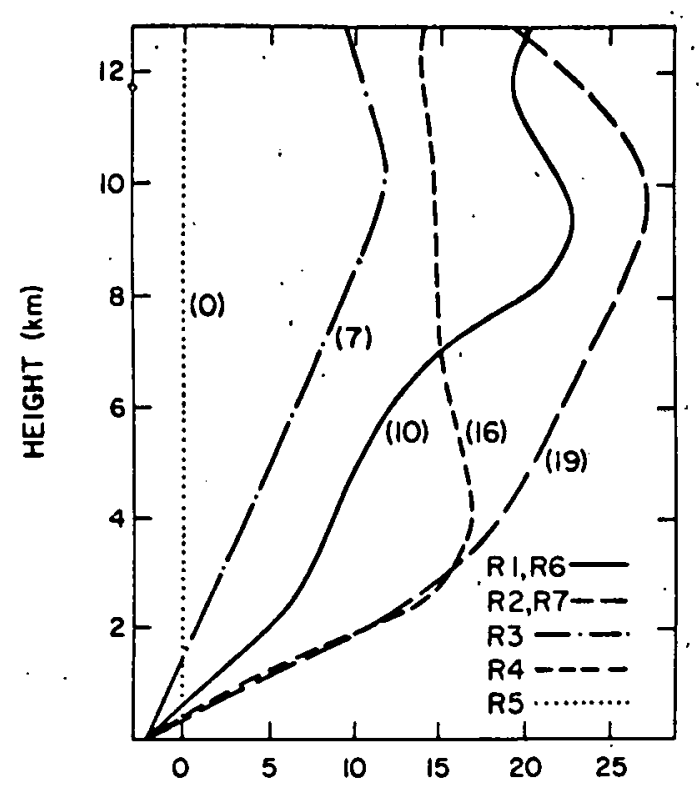

HORIZONTAL WIND SPEED $(\mathrm{m} / \mathrm{sec})$

F1g. 3. The vertical distribution of the horizontal environmental wind used in the model experiments. R1-moderate shear (sol1d); R2-strong shear (long-dashed); R3-weak shear (dash-dotted); R4-m1xed shear (short-dashed); R5-no shear (dotted).

TABLE 1. Summary of the model experiments.

\begin{tabular}{|llrl|}
\hline Number & \multicolumn{1}{c}{ T1tle } & c & Grid \\
\hline R1 & Moderate Shear & 10 & $65 \times 33$ \\
R2 & Strong Shear & 19 & $65 \times 33$ \\
R3 & Weak Shear & 7 & $65 \times 33$ \\
R4 & M1xed Shear & 16 & $65 \times 33$ \\
R5 & "No" Shear & 0 & $65 \times 33$ \\
R6 & Moderate Shear & 10 & $96 \times 33$ \\
R7 & Strong Shear & 19 & $96 \times 33$ \\
\hline
\end{tabular}

All the experiments reported upon here were bogun with a well-rleveloped c1rculation as the initial perturbation. For that reason the most intense stage of the convective circulation 18 reached rather quickly. The results of Exper1ment R1 after about 5 minutes of integration will be described in some detall here in order that varlous features in the results to be presented at other times will be better understood. F1g. 4 shows the results of $\mathrm{Rl}$ at $5.6 \mathrm{~min}$. and 1 ncudes the twn-dimensional fleldis of atream function, ralnwater mixing rat1o, temperature anomaly, and vertical motion. The ralnwater distribution and the cloudwater outline are superimposed upon the stream function field in the top section of this figure and in each of the other cases that w11l be shown. The motion field at this time shows the coex1stence of updraft and downdraft; the updraft exhibits an upshear t1lt and the downdraft orlginates in middle levels located for the most part beneath the updraft. There 18 relative inflow from the left=hend side at middle levela, a portion of which enters into the downdraft c1rculation. The downdraft, upon reachlng the ground, spreads both forward and to the rear. The cloud outline shows a tilted structure also, with new development of cloud occurring on the lower right (downshear) side. The outline of the cloud on the left side follows the line of no vertical. motion between the updraft and the downdraft. The upper portion of the cloud 18 spreading in the horlzontal, mainly in the downshear direction. The ralnwater pattern shows an increasing accumulation of liquid water along the left hand edge of the updraft (max, value greater than $7 \mathrm{~g} \mathrm{~kg}^{-1}$ ). This location 1 e lavored because of production of ralnwater from cloudwater in the updraft and a combination of advection by the tilted updraft with the fall of raindrops relative to the alr which contains them. Rainwater reaches the ground at this time, but not in great amounts.

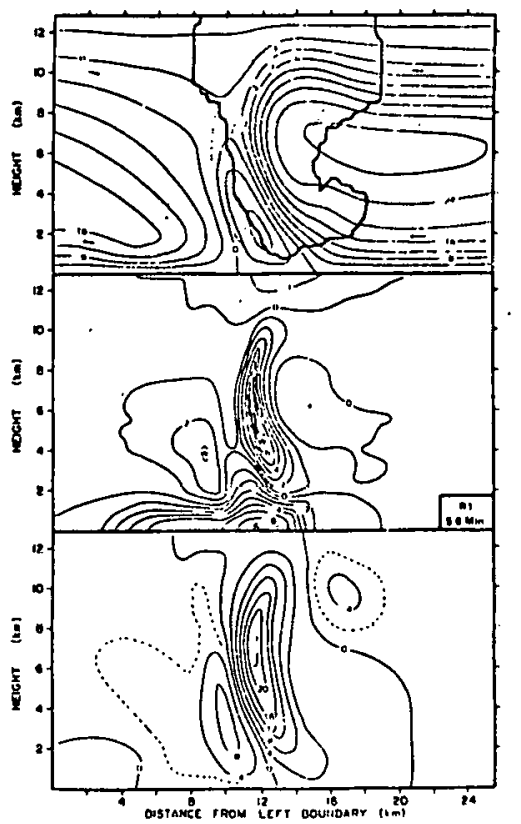

F1g. 4 Regulte of Experiment R1 at 5.6 minutes. Upper: soldd 1 fnes are stream function $\left(10^{3} \mathrm{~kg} \mathrm{~m} \mathrm{~m}^{-1} \mathrm{sec}^{-1}\right)$; dashed lines are rainwater mixing ratio $\left(8 \mathrm{~kg}^{-1}\right)$; scalloped Ilnes are cloud outline. Middle: temperature anomaly $\left({ }^{\circ} \mathrm{K}\right)$. Lower: vert1cal wind speed $\left(m \sec ^{-1}\right)$.

The temperature anomaly pattern at this time shows a warm region with a maximum slightly greater than $7 \mathrm{C}$ located along the axis of the updraft, due to condensational heating in the updraft. A relatively cool area exista just to the left of the warm area, extend1ng upward from a cold region at the ground (greaterr than $-6 \mathrm{C}$ anomaly). Th1s relatively cool region results from evaporation of rain in the downdraft. To the left of this a warm regton (max. $3 \mathrm{C}$ anomaly) exists, resulting from dry adlabatic warming in descending alr with 11ttle or no rain in 1t. To the right of the updraft is a slightly cool region resulting from dry adlabatic cooling in upward moving alr contalning little or no condensate.

The vertical motion pattern shows the maximum upward motion to be more than $22 \mathrm{~m} \mathrm{sec}^{-1}$ located at about $7 \mathrm{~km}$ height. The dowpward maximum 18 ol1ghtly greater than $10 \mathrm{~m} \mathrm{sec}^{-1}$ located at about $3 \mathrm{~km}$ height. There are reglons of downward "compensation" outside the cloud, located on 
the right in the upper troposphere and on the left, merging with the rain-augmented downdraft, between the cloud and the left boundary.

The results of Experiment $R I$ are shown at $16.3 \mathrm{~min}$. in Fig. 5. The most apparent change here is the lessened Intensity and lack of organ1zation in the system. At least three reasons may be given for this change in shape and intensity, and all are related to the two-dimensional constraint imposed in thlo model.

1) The air in the downdraft upon reaching the ground must spread elther forward or to the rear, whereas in nature $1 t$ can and does spread to some extent into the third dimenolon. Since the updraft originates at the micro-cold front at the leading edge of this cold downdraft alr, the lower updraft undergoes an excessive downshear displacement. This means that in order for the updraft to maintain itself at 1ts orlginal intensity, it must regenerate in middle levels on $1 t s$ right hand side. This regeneration is prevented because

2) The downward motion in middle levels to the right of the original cloud 18 advecting dry air into the updraft. Th1s downward motion 18 more intense than it would be in nature where some of the "compensation" takes place out of the plane of this model.

3) The strong relative left-to-right flow in upper levels must take part in the in-cloud circulation in this two-dimensional case, whereas in nature a great deal of the alr must go around the cloud, since the precipitation-filled cloud must to sume extcrit act as an obstacle to the flow (cf. Fankhauser, 1971). Thus the strong horlzontal winds aloft in this two-dimensional case tend to bend the updraft in a downshear sense in upper levels, and some rain tends to fall on the right hand side of the cloud. Th1s creates additional difficulty for the regeneration process to occur continuously in that vicinity.

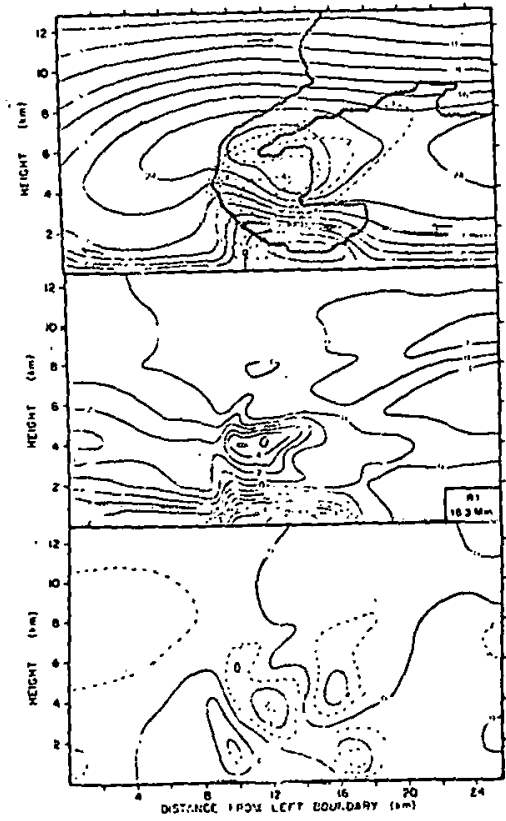

F1g. 5. Same ag Fig. 4 but fnr Experiment RI at 16.3 minutes.
Figure 6 shows the time variation of maximum updraft speed, maximum dowridraft speed, and maximum rainwater mixing ratio for Experiment $R 6$ which is an extension of Experiment R1. During the 20-. 30 minute perlod following initiation, the flow (not shown) is quite simple. It is characterized by the forced ascent of air over the cold "dome" near the surface with essentlally undisturbed conditions (11ttle or no vertical motion) above $5 \mathrm{~km}$. It is seen from Fig. 6, however, that significant redevelopments do occur centered at about 42,59 , and 104 minutes. F18. 7 shows the varlable flelds at approximately 42 minutes. The structure of the motion, thermal, and ralnwater flelds at this time is basically the same as that shown In F1g. 4. Th1s 18 also true of the developments at 59 and 104 minutes. Thus, in this twodimenslonal treatment of the problem, the longev1ty of the system is not due to a quasi-steady state condition, but to the apparent continuous band structure of the convection, persistent because of an aperiodic regeneration.

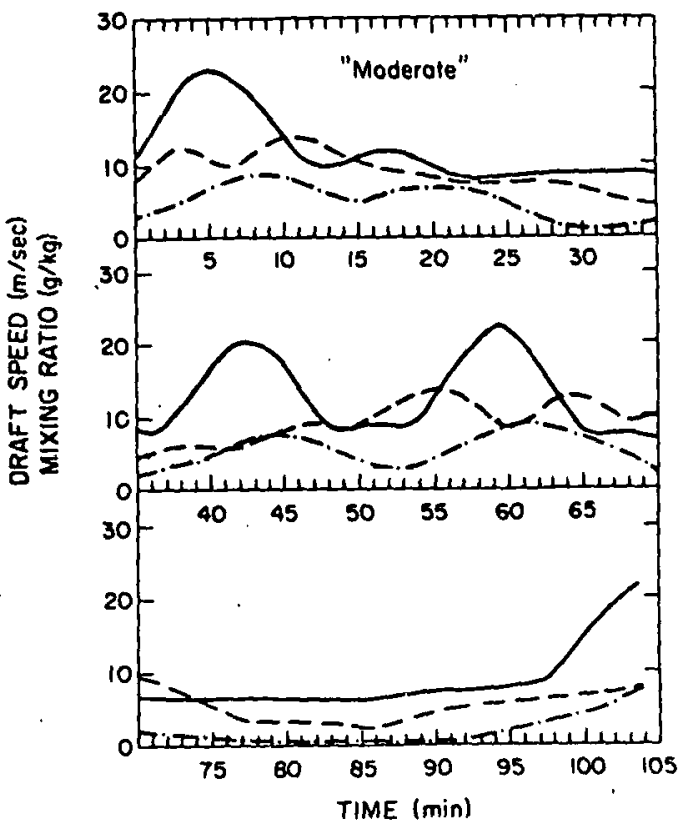

F1g. 6. For Experiment $R 6(R 1)$, the vartation with time of the magnitude of the maximum upward motion (sol1d), maximum downward motion (dashed), and maximuin rainwater mixing ratio (dash-dotted).

Referring again to F1g. 6 , in the case of each development the maximum upward motion 18 followed by a maximum in rainwater mixing ratio and then by a maximum in downdraft speed. The interpretation here 15 that rain continues to be produced in the updraft even though the speed is decreasing. At the same time the rain is falling and does so at a greater rate (relative to the earth) as the updraft speed decreases. The two effects (production and falling) result in a maxiium in rainwater mixing ratio which lags the maximum upward motion by about two minutes in each case. As the rain falls, the downdraft speed increases due to negative buoyancy resulting from evaporational cooling and due to the weight of the rain. Thus the maximum downdraft speed lags the muxluium ralnwater mixing rat10 by about three minutce and the maximum updraft speed by about 


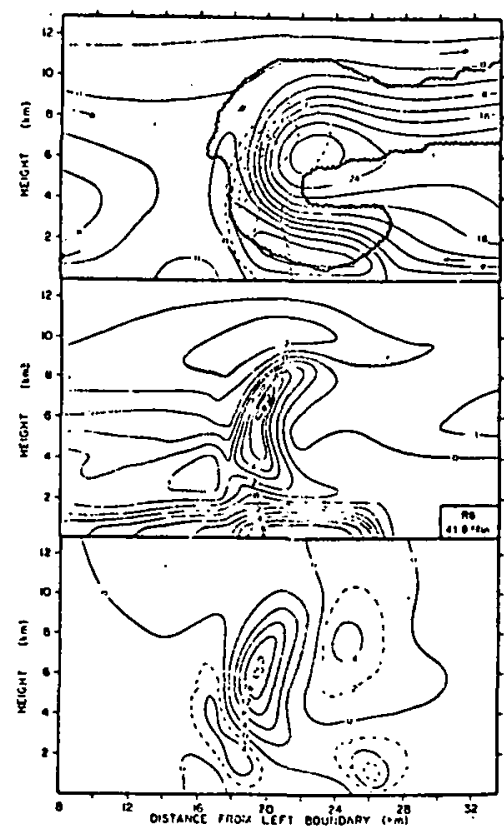

F18. 7 Same as Fig. 4 but for Experiment RI at 41.9 minutes.

five minutes in each case. It should also be noted that there are actually two maxima in the downdraft speed (temporal maxima) during each development. First, the increase in maximum updraft speed and vertical development of the updraft is accompanied by an increase in maximum downdraft speed purely through mass compensation. This downward compensation decreases in maximum value as it spreads over a larger area during the time that the updraft 18 at 1 ts maximum intensity. Th1s is followed by the concentration of this downward motion over a smaller area (in the rain area) and an increase in maximum value as rain produced in the updraft falls on the upohear side of the cloud.

The results of Experiments R3, R4, and R5 w111 not be shown here because they include environmental wind shears unlike those characteristic of squall line situations. However, a brief description of each will now be given. In the weak ohear experiment (R3), a loss of 1ntensity and organization occurs rather quickly in that (a) the upward motion area 18 narrower because of the weaker relative low-level inflow and (b) a separation of the updraft occurs more dramatically than in the moderate-shear case because of the more rap1d left-to-right movement of the surface cold air relative to the mid-level updraft. Experiment R4, where the wind shear 1s very strong in the loweat $3 \mathrm{~km}$ and very weak and of the opposite sign above that level, was run in an attempt to see the effect of not having strong winds in upper levels, which in a two-dimensional experiment, have an exaggerated effect upon the upper parts of convective clouds. The result was that the upshear t1lting updraft had a longer ilfetime than in ocher experimenta, and that the downdraft was conslderably stronger because the rain had fallen in the same area for a long time. Experiment R5 was run with no environmental wind shear. This development most eloooly resambles the latter two-thirds of the life cycle of an "air mass" cumulonimbus as described by Byers and
Braham (1949). The motion 18 primar1ly upward in a non-t1lting updraft in the early stages with a large accumulation of 11quid water, followed by the development of a strong downdraft and the dissipation of the updraft as the rain falls out.

Experiment $R 2$ differs from $R 1$ in that the vertical shear of the horizontal wind is atronger in the mean than in R1, and much stronger below $3 \mathrm{~km}$ (see F1g. 3). The results of Experiment R2 at about $5 \mathrm{~min}$, are shown in Fig. 8. The updraft ohows a olight upshear t1lt, but not so pronounced as in RI (ff. F1g. 4). More raln 1s present ( $>98 \mathrm{~kg}-1$ ) than in Experiment Rl at this time because of the stronger ( $>28 \mathrm{~m} \mathrm{sec}^{-1}$ ) and broader updraft and additionsl condensation. Th1s rain, because of the more vertical updraft, rema1ns ouspended in the updraft to a greater extent than In $R 1$ and 88 a result does not maintain so otrong a downdraft during much of 1 ts early history. Once again downward "compensation". Is falrly strong ( $4 \mathrm{~m}^{6 e c^{-1}}$ ) to the right of the updraft in upper levels in the anvil outflow.

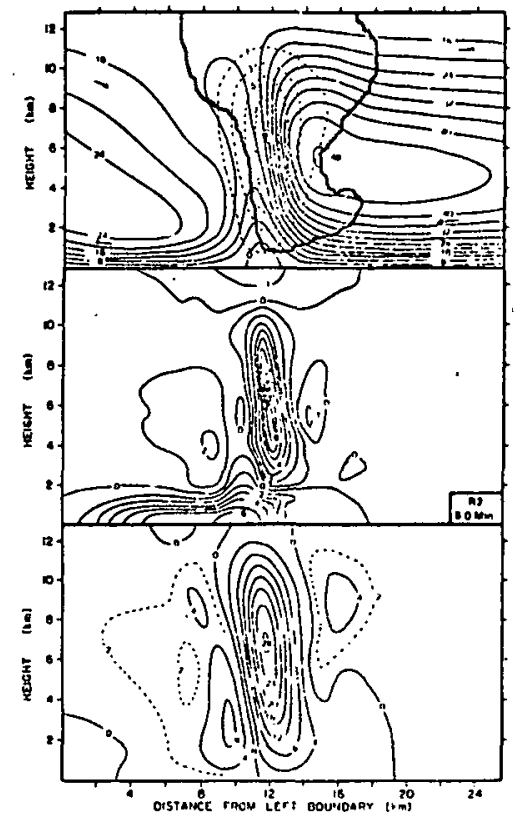

F18. 8

Same as F1g.' 4 but for Experiment R2 at 5.0 minutes.

The time evolution of this experiment is shown in F1g. 9. Once aga1n, following the 1088 of organization and Intensity of the firat development, redevelopment occurs at aperiodic intervals ( 38 and 54 min.). A comparison of the time evolution of Exper1ments R6 and R7 (F1gs. $6 \& 9$ ) reveals that the timing of the developments is nearly the same, except that the development at 95-100 min. Is not present in the strong shear case due to problems along the right lateral. boundary from 83 minutes on. The maximum upward motion during developments appears to be about the same on the average; however, the developments in the strong shear case are longer lasting and include broader updraft reglons (as revealed by an examination of the two-dimensional fields of vertical wind speed during lndividual developments). As a result more rain 18 produced and falls to the ground in the stronger ohear developments. Th1s increased intensity with increaged 
wind shear is evidently due to the increased relat ive inflow of warm molst a1r in low levels that accompanies the increased horizontal system speed. Since the downshear tilting of the updraft in upper levels is due to the inclusion of strong hordzontal winds from the environment, the art1ficial effect of the two-dimensional constraint here $1 s$ to prevent a strong updraft from penetrating to high levels. The stronger development at 5 minutes in Experiment R7 occurs because the time is not sufficient for the shear to affect the structure as it does in the developments at 38 and 54 minutes. Fig. 9 also reveals that during the perlod of the two developments occurring between 32 and 67 minutes, the maximum ra1nwater mixing tatlo does not decrease below $58 / \mathrm{kg}$. If such a storm were vlewed by PPI radar it would be assumed that a single development of long duration had occurred.

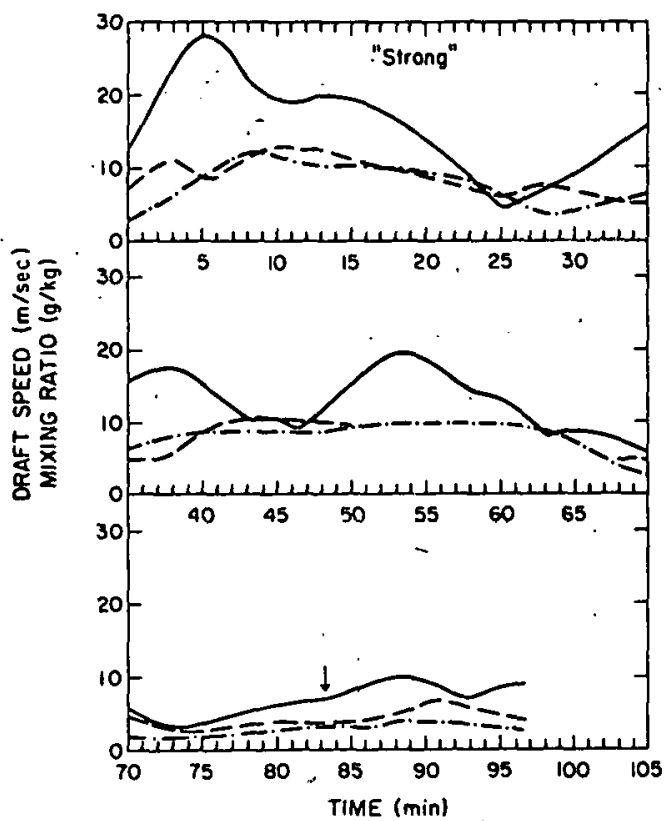

F1g. 9 Same as Fig. 6 but for Experiment R7 (R2). The arrow denotes the time when the maximum upward motion shifte to near the boundary.

Comparisons w111 now be made between model calculations and natural observationa. Rainfall amounts resulting from individual model clouds passing over flxed points on the ground are approximately 0.40 inches. Horizontal wind speeds near the ground in the cold outflow behind the wicro-cold front are in the $20-25 \mathrm{~m} / \mathrm{sec}$ range (these should be compared with sustalned winds rather than short-lived gusts which cannot be resolved with a 400 meter $g \times 1 d$ ). Radar reflectivities calculated from model ralnwater mixing ratios compare favorably with those measured in nature. An attempt is also made to compare the vertical temperature structure within the cold "dome" with that in a natural situation. For detalls of how these figures used for comparison were arrived at, see lane (1972).. F1.8. 10 shows that within the cold "dome" which exists as a result of the convection, model calculations agree with observed measurements between the surface and about $1.5 \mathrm{~km}$, but the observed case shows a greater total decrease in temperature $\left(2^{\circ}\right.$ to $3^{\circ} \mathrm{r}$ colder) between 2 and $3 \mathrm{~km}$. The warmer temperatures above $1.5 \mathrm{~km}$ in the model calculations probably result from the moderate downward motion and adiabatic warming in middle-level dry alr to the left of the cloud and rain area. Th1s downward motion may not be so strong at this location in nature. Differences might also result from particular conditions in the observed case which was chosen.

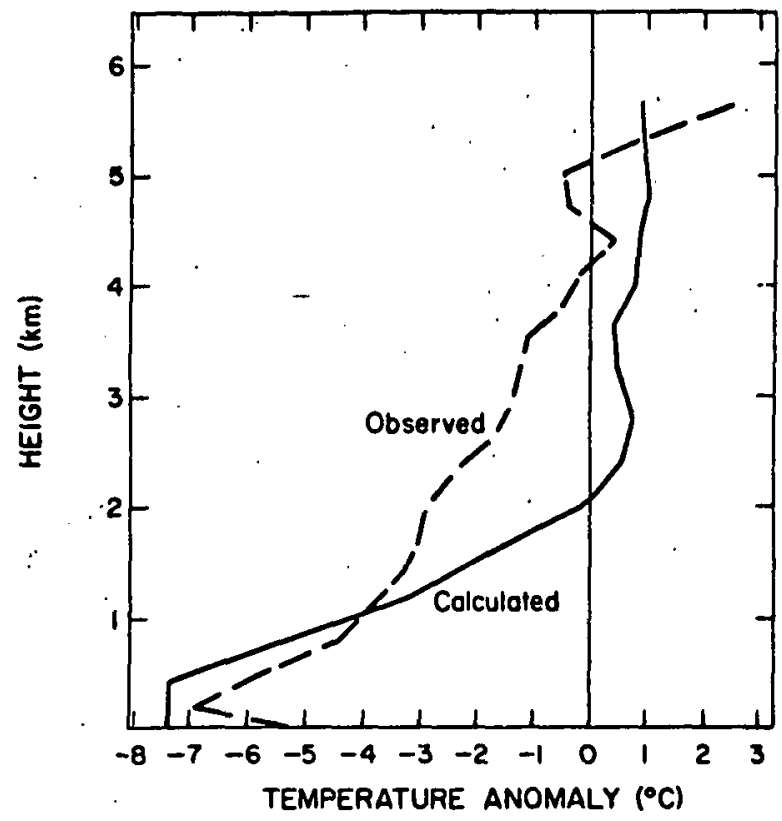

F1g. 10 Temperature anomaly within the cold dome for Experiment R6 at 28.9 minutes (solid) and for an observed case of May 29, 1968 In Oklahoma (dashed).

\section{CONCLUSIONS}

Four points are worthy of note. (1) The basic structure of the in-cloud circulations arrived at in this model agrees quite well with the basic structure hypothesized in qualitative physical models in the past. (2) The effect of strong vertical shear is to increase the intensity and longevity of cloud circulations, but at the same time there 18 an artifictal shearing off of cloud tops because of the imposed twodimenotonality. (3) The results of the calculatlons point to three specific areas where the third dimension 18 important in the squall line thunderstorm circulation. Experimentation in the future should therefore be carried out taking into account effects of the third dimension. (4) From the fact that the squall line in this model undergoes regeneration (at 1rregular intervals), it 1s Inferred that once Inltiated such a system is self-. maintaining as long as it remains within a convectively unstable alr mass whose motion 18 characterized by moderate to otrong vertical shear.

\section{Acknowledgements}

I am grateful to Prof. N. E. LaSeur of Florlda State UnIveralty for his. numerous suggestions during the course of this research and to Dr. C. 1. . Newton for his commente upon the work. 
The work was supported by grants from the National Severe Storms Laboratory, Norman, Oklahoma. Computing was done at the Florida State University Computing Center and at the Computing Fac1lity of the National Center for Atmospher1c Research.

\section{REFERENCES}

Árnason, G., R. S. Greenfleld, and E. A. Newburg, 1968: A numerical experiment in dry and molst convection including the rain otage. J. Atmos. Sc1., 25, 404-415.

Bates, F. C., 1961: The Great Plains squall 11ne thunderatorm - A model. Ph.D. Thes1s, St. Loulo Univeralty.

Browning, K. A., and F. H. Ludlam, 1962: Air flow in convective storms. Quart. J. Roy. Meteor. Soc., 88, 117-135.

Byers, H. R., and R. R. Braham, 1949: The Thunderstorm. Washington, D.C., U.S. Govt. Printing Office, 287 pp.

Dantelsen, E. F., R. Bleck, and D. A. Morr18, 1972 : Ha11 growth by stochastic collection in a cumulus model. J. Atmos. Sc1., 29, 135-155.

Fankhauser, J. C., 1971: Thunderstorm-environment Interaction determined from a1rcraft and radar observations. Mon. Wea, Rev., 99. 171-192.

Hane, C. E., 2972: Squall line structure and malntenance: numerical experimentation. Report No. 72-5, Florida State Univera1ty, Grants E22-19-7I(G) and E22-58-69(G) from NOAA, 190 PP.

Kessler, E., E. Newburg, P. Feter1s, and G. W1ckham, 1961-1964: Relationsh1ps between trop1cal precipitation and k1nematic cloud modele. Reporta 1-5, Travelers Research Center, Contract DA36-039 SC 89099.

Ludlam, F. H., 1961: The ha1lstorm. Weather, 16, 152-162.

Malkus, J. S., and G. W1tt, 1959: The evolution of a convective element: a numerical calculation. The Atmosphere and the Sea in Mot1on. Ed. B. Bolln, New York, Rockefeller Inst1tute Press, 425-439.

Marsha11, J. S., and W. McK. Palmer, 1948: The distribution of ralndrops with o1ze. J. Meteor., 5, 165-166.

Murray, F. W., 1970: Numerical models of a trop1cal cumulus cloud with bilateral and axial syometry. Mon. Wea. Rev., 98, 14-28.

Newton, C. W., 1950: structure and mechan1em of the prefrontal oquall 11ne. J. Meteor., I, 210-222.

- 1963: Dynamics of severe convect1ve ecorms. Meteorological Monographe, 5. 33-58.
Normand, S1r Charles, 1946: Energy in the atmosphere. Quart. J. Roy. Meteor. Soc., 72, 145-167.

Ogura, Y., and J. G. Charney, 1962: A numer1cal model of thermal convection in the atmosphere. Proc. International Symposium on Numerical Weather Prediction, Met. Soc. of Japan, Tokyo, Japan, 431-451.

- 1963: The evolution of a molst convective element in a shallow, conditionally unstable atmosphere: a numerical calculation. J. Atmos. Sc1., 20, 407-424.

- and T. Takahash1, 1971: Numer1cal s1mulation of the $11 \mathrm{fe}$ cycle of a thunderatorm cell. Mon. Wea. Rev., 99, 895-911.

Orollle, B. D., and J. Y. LIu, 1969: Numer1cal modeling of precipitation and cloud shadow effects on mountain-1nduced cumull. $\mathrm{J}$. Atmos. 6c1.. 26, 1283-1298.

Sasak1, Y., 1959: A numer1cal experiment for oquall line formation. J. Meteor., 16. 347-353.

Schlealnger, R. E., 1972: A numerlcal model of deep molat convection: the influence of amblent conditions and Internal physical mechanlems. Studies of the Atmosphere Using Aerospace Probinge/Annual Report-1971; Vo1. 1, The University of W18consin, Grant E-230-68-(G) from ESSA.

S1mpson, J., and V. W1ggert, 1969: Modelo of preclpitating cumulus towerb. Mon. Wea. Rev., 97, 471-489.

Squires, P., and J. S. Turner, 1962: An entra1nIng jet model for cumulonimbus updraughts. Tellus, 14, 422-434.

Srivastava, R. C., 1967: A otudy of the effect of precipitation on cumulus dynamics. J. Atmog. Sc1., 24, 36-45.

Takeda, T., 1971: Numerical e1mulation of a preclpitating convective cloud The formation of a 'Iong-laet1ng' cloud. J. Atmos. Sc1.' $28,350-376$.

We1nste1n, A. I., 1970: A numerical model of cumulue dynamlce and microphyo1ce. $J$. Atmos. Sc1, 27, 246-255. 